\title{
Synthesis and structure of novel 4,5-dihydro- $1 H$-pyrazoles: salicylic acid based analgesic agents
}

\author{
Pablo Machado, ${ }^{a}$ Fernanda A. Rosa, ${ }^{\text {a }}$ Marcelo Rossatto, ${ }^{a}$ Gabriela da S. Sant'Anna, \\ Patricia D. Sauzem, ${ }^{b}$ Rubia M. Siqueira da Silva, ${ }^{\text {a }}$ Maribel A. Rubin, ${ }^{b}$ Juliano Ferreira, \\ Helio G. Bonacorso, ${ }^{a}$ Nilo Zanatta, ${ }^{a}$ and Marcos A. P. Martins ${ }^{a}{ }^{*}$ \\ ${ }^{a}$ Núcleo de Química de Heterociclos (NUQUIMHE), Departamento de Química, Universidade \\ Federal de Santa Maria, 97105-900, Santa Maria, RS, Brazil \\ ${ }^{b}$ Laboratório de Neurotoxicidade e Psicofarmacologia, Departamento de Química, Universidade \\ Federal de Santa Maria, 97105-900, Santa Maria, RS, Brazil \\ E-mail: mmartins@base.ufsm.br
}

\begin{abstract}
An efficient method to obtain 4-alkoxy-2-oxo-but-3-enoic acid ethyl esters $\left[\mathrm{EtO}_{2} \mathrm{CC}(\mathrm{O}) \mathrm{C}\left(\mathrm{R}^{2}\right)=\mathrm{C}\left(\mathrm{R}^{1}\right) \mathrm{OR}\right.$, where $\mathrm{R}=\mathrm{Me}, \mathrm{Et} ; \mathrm{R}^{1}=\mathrm{Me}, \mathrm{Ph}, 4-\mathrm{MeC}_{6} \mathrm{H}_{4}, 4-\mathrm{BrC}_{6} \mathrm{H}_{4}, 4-\mathrm{FC}_{6} \mathrm{H}_{4}$; $\mathrm{R}^{2}=\mathrm{H}, \mathrm{Me}$ ] from the acylation of enol ethers or acetals with ethyl oxalyl chloride is reported. The cyclocondensation reaction of these substrates and their trifluoromethylated analogues $\left[\mathrm{CF}_{3} \mathrm{C}(\mathrm{O}) \mathrm{C}\left(\mathrm{R}_{2}\right)=\mathrm{C}(\mathrm{OR}) \mathrm{R}^{1}\right]$ with salicylic hydrazide furnished a series of ethyl 5-hydroxy-1-(2hydroxybenzoyl)-4,5-dihydro-1H-pyrazole-5-carboxylates and 5-hydroxy-5-trifluoromethyl-4,5dihydro-1H-1-(2-hydroxybenzoyl) pyrazoles, respectively. The structure of the compounds was supported by crystallographic data. Orally administrated, one of each of the series of pyrazoles $\left(\mathrm{R}^{2}=\mathrm{H}, \mathrm{R}^{1}=\mathrm{Me}\right)$ showed significant analgesic effects in the writhing test in mice. The decrease in pain-related behavior obtained was close to that achieved with aspirin activity.
\end{abstract}

Keywords: Pyrazoles, enones, salicylic acid, X-ray, analgesia

\section{Introduction}

The synthesis of pyrazole and its analogues has been a subject of consistent interest because of the wide range of applications for such heterocycles in the pharmaceutical and agrochemical industries. ${ }^{1}$ Therefore, extensive research efforts are continually directed at the discovery of new heterocycles with appropriate pharmacological effects. Among their range of properties, the compounds containing a pyrazole scaffold have been shown to exhibit HIV-1 reverse transcriptase and IL-1 synthesis inhibition, as well as antihyperglycemic, antibacterial, sedativehypnotic, anti-inflammatory, antipyretic and analgesic activity. ${ }^{2}$ In part, the anti-inflammatory, 
antipyretic and analgesic properties of pyrazole derivatives have been associated with the inhibition of prostaglandin biosynthesis in the cyclooxygenase step. ${ }^{3}$ However, their analgesic effects may involve other mechanisms, such as the release of endogenous opioids, ${ }^{4}$ the modulation of nitric oxide production, ${ }^{5}$ and the inhibition of excitatory amino acid receptors. ${ }^{6}$

The synthesis of pyrazole derivatives has been well explored using the so-called [3+2] atom fragments, where $\beta$-diketones or $\alpha, \beta$-unsaturated ketones are used as the 3 -atom building block and hydrazines as the 2-atom fragment. In the last decade, our research group has reported the general synthesis of 1,1,1-trihalo-4-alkoxy-3-alken-2-ones, 3-atom building blocks, and demonstrated their usefulness in heterocyclic preparations. ${ }^{7}$ In addition, 1,1,1-trichloro-4-alkoxy3-alken-2-ones have been found to be powerful precursors for the synthesis of carboxyl derivative heterocycles, as the trichloromethyl group undergoes a hydrolysis reaction when treated with either alcohols, sulfuric acid $(96 \%)$ or their mixture in water. ${ }^{8}$ However, the use of unsymmetrically substituted precursors often leads to a mixture of regioisomers hindering the use of this method for regiospecifically obtaining the carboxyalkylpyrazole derivatives by a onepot procedure. ${ }^{9}$ Thus, we became interested in a 1,3-dielectrophilic precursor, already substituted with a carboxyalkyl group, aiming toward a more general, efficient and regiospecific synthesis of such heterocyclic compounds. With regards to the synthesis of carboxylpyrazoles, other methods and precursors have been found in the literature, ${ }^{10}$ however, they have been reported to present disadvantages, mainly due to their limited scopes and the use of substrates not readily available. We thus decided that the reported acylation ${ }^{11 a}$ of enol ethers with ethyl oxalyl chloride deserved reinvestigation as a general method to synthesize 4-alkoxy-2-oxo-3-butenoic esters (1,3dielectrophilic compounds), because of the simplicity of the procedure. Another method that has been performed for the synthesis of compounds such as 2a (Scheme 2), consists in the methylation of ethyl 2,4-dioxopentanoate with diazomethane. However, this method showed serious problems, such as a mixture of isomers, low yields and also the limitation of the synthesis of only one compound. ${ }^{11 \mathrm{~b}}$ Furthermore, an analogous to compound $\mathbf{2 b}$ (Scheme 2) has also been reported in the literature, this compound showing an ethoxy instead of a methoxy group at the 4 position of the 4-alkoxy-2-oxo-3-butenoic ester. ${ }^{11 \mathrm{c}}$

In addition, as part of our research program, we were interested in obtaining compounds endowed with anti-inflammatory, antipyretic and mainly analgesic activity. Our contributions in this field include the investigation of novel pyrazole derivatives in animal models of inflammation, fever and pain. ${ }^{12}$ In that study, the presence of 5-trihalomethyl-4,5-dihydro- $1 \mathrm{H}$ pyrazole $^{12 \mathrm{a}-\mathrm{d}}$ as well as of a 5-ethoxycarbonyl pyrazole ${ }^{12 \mathrm{e}}$ ring were a determining factor in obtaining compounds with good antipyretic and analgesic properties against neurogenic, inflammatory and visceral pain in rodents. Thus, considering the analgesic efficacy of 4,5dihydro- $1 H$-pyrazoles, we intend to explore the hypothesis that their hybridization with salicylic acid can supply the design of novel potent analgesic agents (Scheme 1). Salicylic acid is known to present numerous therapeutic applications such as: anti-arthritic, antineuralgic, antirheumatic, anti-thrombotic, keratolytic, antiseptic, anti-inflammatory, antipyretic and analgesic activity. ${ }^{13}$ Therefore, the hybridization of these two scaffolds, which share analgesic and antipyretic 
properties, may contribute in a synergistic manner to bring about an evolution of activity in a second-generation of molecules. ${ }^{13}$
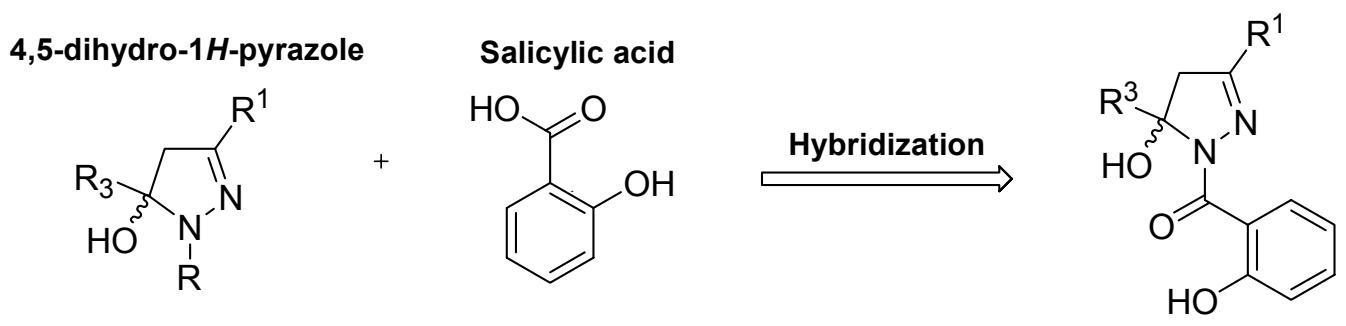

$\mathrm{R}^{3}=\mathrm{CO}_{2} \mathrm{Et}, \mathrm{CF}_{3}$

\section{Scheme 1}

\section{Results and Discussion}

The acylation of enol ethers 1a,f with ethyl oxalyl chloride (Scheme 2) in pyridine was carried out with an equal molar ratio using anhydrous chloroform as solvent. The most satisfactory results were obtained when the reactions were performed at between $0^{\circ} \mathrm{C}$ and room temperature for $16 \mathrm{~h} \mathrm{(2f)} \mathrm{or} \mathrm{from} 0^{\circ} \mathrm{C}$ to $35^{\circ} \mathrm{C}$ for $18 \mathrm{~h} \mathrm{(2a)}$.

In an attempt to expand the scope of the reaction by making use of observations made previously in our laboratory, ${ }^{14}$ we also performed the acylation of acetophenone acetals $\mathbf{1 b - e}$ with ethyl oxalyl chloride. This activated acyl halide reacted with the enol ethers, generated in situ from the respective acetals, furnishing the 4-Aryl-4-methoxy-2-oxo-3-butenoic esters 2 b-e as a one-pot procedure in good yields. This reaction was carried out using acetal, pyridine and the acylating agent at a molar ratio of 1:2:2, in reflux of chloroform for $5 \mathrm{~h}$. The second equivalent of acylant trapped the methoxyl group, liberated from acetal, forming methyl ethyl oxalate, which was separated from the product by distillation. The acetals $\mathbf{1 b - e}$ were synthesized from the reaction of the respective ketone with trimethyl orthoformate in the presence of $p$ toluenesulfonic acid. ${ }^{15}$ 


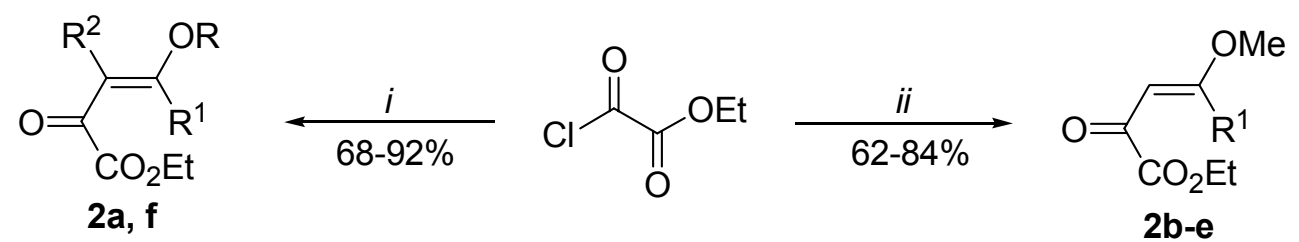

\begin{tabular}{ccccccc}
\hline $\mathbf{1 , 2}$ & $\mathbf{a}$ & $\mathbf{b}$ & $\mathbf{c}$ & $\mathbf{d}$ & $\mathbf{e}$ & $\mathbf{f}$ \\
\hline $\mathrm{R}$ & $\mathrm{Me}$ & - & - & - & - & $\mathrm{Et}$ \\
$\mathrm{R}^{1}$ & $\mathrm{Me}$ & $\mathrm{Ph}$ & $4-\mathrm{MeC}_{6} \mathrm{H}_{4}$ & $4-\mathrm{BrC}_{6} \mathrm{H}_{4}$ & $4-\mathrm{FC}_{6} \mathrm{H}_{4}$ & $\mathrm{H}$ \\
$\mathrm{R}^{2}$ & $\mathrm{H}$ & - & - & - & - & $\mathrm{Me}$ \\
\hline
\end{tabular}

(i) $\mathrm{R}^{2} \mathrm{CH}=\mathrm{C}(\mathrm{OR}) \mathrm{R}^{1}(\mathbf{1 a}, \mathbf{f}), \mathrm{CHCl}_{3}, \mathrm{Py}, 0^{\circ}$ to $35^{\circ} \mathrm{C}, 16-18 \mathrm{~h}$

(ii) $\mathrm{CH}_{3} \mathrm{C}(\mathrm{OMe})_{2} \mathrm{R} 1(\mathbf{1 b}-\mathbf{e}), \mathrm{CHCl}_{3}, \mathrm{Py}, 0^{\circ}$ to $65^{\circ} \mathrm{C}, 5 \mathrm{~h}$.

\section{Scheme 2}

The ${ }^{1} \mathrm{H}$ and ${ }^{13} \mathrm{C}$ NMR spectra of products $\mathbf{2 a - f}$ showed sets of signals corresponding to the proposed structures with the vinylic hydrogen $(\mathrm{H}-3)$ at a range of $\delta 6.13-7.59$. The ${ }^{13} \mathrm{C}$ NMR showed two typical signals assigned to the vinylic carbons on average at $\delta 102.5(\mathrm{C}-3)$ and 172.0 (C-4).

On the basis of X-ray experiments, it was established that the methoxy [O(10)-C(11)] and the carbonyl group $[\mathrm{C}(6)-\mathrm{O}(7)]$ were situated trans to one another on the double bond $((E)$ configuration, Figure 1) with a torsional angle of $172.6(15)^{\circ}$ in the synthesized compound 2e.

In a second step, our efforts were focused on the synthesis of new salicylate-containing dihydropyrazoles and on the validation of the method of hybridization used for obtaining compounds endowed with analgesic activity. Although some trifluoromethyl salicylatecontaining dihydropyrazoles have been described in the literature, ${ }^{16}$ the presence of this moiety has been justified due to the unique physical and biological properties of fluorine when attached to drug-like compounds. ${ }^{17 a}$ In many systems, the substitution of the methyl group by a trifluoromethyl group, for example, results in added lipophilicity $\left[\pi\left(\mathrm{CF}_{3}\right)=1.07\right.$ versus $\pi\left(\mathrm{CH}_{3}\right)$ $=0.50],{ }^{17 \mathrm{~b}}$ which may lead to easier absorption and transportation of the molecules within biological systems and thereby improve the overall pharmacokinetic properties of the compounds.

The synthetic procedure for the preparation of such compounds employed two simple protocols: $(i)$ the reaction of methyl salicylate with hydrazine hydrate to give the corresponding hydrazide and ( $i$ ) the cyclocondensation reaction of the hydrazide 4 with appropriate $\alpha, \beta$ unsaturated ketones 2,5 (Scheme 3). The salicylic hydrazide 4 was readily available from the reaction of hydrazine hydrate with ester 3 in reflux of anhydrous ethanol for $5 \mathrm{~h}$, in accordance with the previously reported procedure. ${ }^{19}$ The crystalline product was isolated in good yield (78\%). The second step was carried out from the cyclocondensation of previously synthesized 4- 
alkoxy-2-oxo-3-butenoic esters 2 and 4-alkoxy-1,1,1-trifluoro-3-alken-2-ones $\mathbf{5}$ with salicylic hydrazide 4.

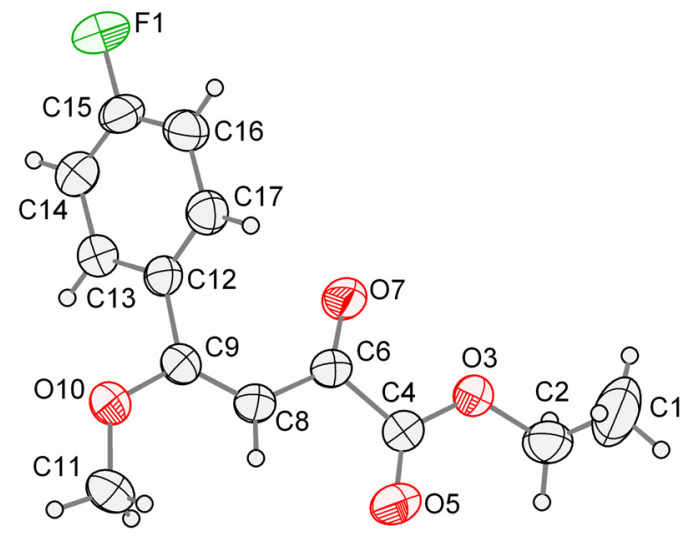

Figure 1. ORTEP ${ }^{18}$ obtained from crystal structure of (E)-4-(4-fluorophenyl)-4-methoxy-2-oxobut-3-enoic acid ethyl ester (2e). Displacement ellipsoids are drawn at the 50\% probability level.

The 4-alkyl(aryl)-1,1,1-trifluoro-3-alken-2-ones 5a-f were synthesized from the reaction of the respective enol ether (1a,f) or acetal (1)-e) with trifluoroacetic anhydride according to previous publications. ${ }^{20}$ The reaction of $\alpha, \beta$-unsaturated ketones $\mathbf{2 , 5}$ with salicylic hydrazide was conducted in the presence of methanol or ethanol at reflux for $16 \mathrm{~h}$. The 4,5-dihydro- $1 \mathrm{H}$ pyrazoles 6,7 were obtained regiospecifically with satisfactory yields (60-96\%). As can be verified from extensive reports from our laboratories, ${ }^{7 a}$ the 4,5 -dihydro- $1 H$-pyrazoles were highly stable and could be isolated. In most cases, these compounds were obtained when the N-1 or C-5 was substituted by a strong electron-withdrawing group that hindered the elimination of water and a subsequent aromatization of the pyrazole ring. ${ }^{1 \mathrm{a}, \mathrm{a}}$ In the present study, we synthesized compounds that possessed in their structures a combination of effects that avoided the dehydration reaction: a 2-hydroxybenzoyl group attached on N-1 and an ethyl carboxylate or trifluoromethyl group on C-5.

Pyrazoles 6,7 showed sets of ${ }^{1} \mathrm{H}$ and ${ }^{13} \mathrm{C}$ NMR data that corresponded to the proposed structures. Compounds 6a-e and 7a-e showed ${ }^{1} \mathrm{H}$ NMR chemical shifts of the diastereotopic methylene protons $(\mathrm{H}-4 \mathrm{a}$ and $\mathrm{H}-4 \mathrm{~b})$ as a characteristic $\mathrm{AB}$ system and as a doublet at the range of $\delta 2.97-3.55$ and another doublet at the range $\delta 3.20-3.75$, respectively, with a geminal coupling constant at the range of ${ }^{2} J=18-19 \mathrm{~Hz}$. The ${ }^{13} \mathrm{C}$ NMR spectra showed typical chemical shifts of 4,5-dihydro- $1 H$-pyrazole rings on average at $\delta 157.0$ (C-3), 46.4 (C-4), 88.4 (C-5, 6a-f), 91.2 (C-5, 7a-f), $168.2\left(\mathrm{CO}_{2} \mathrm{Et}\right), 123.5\left(\mathrm{CF}_{3}\right)$. It is noteworthy that $\mathrm{C}-5$ showed similar chemical shifts for series 6 and 7, emphasizing the similarity of the negative inductive effect of ethyl carboxylate and the trifluoromethyl group. 
<smiles>[X]OC(=O)c1ccccc1O</smiles>

3

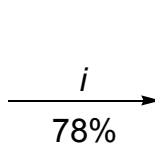

$78 \%$

10

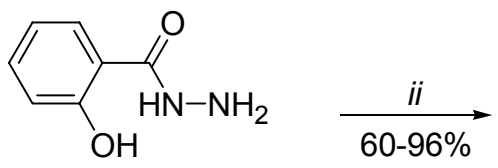

4<smiles>[R]C1=NN(C(=O)c2ccccc2O)[C@]([R])(O)C1[R]</smiles>

6b-f, 7a-f

\begin{tabular}{ccc}
\hline & $\mathbf{2 , 6}$ & $\mathbf{5 , 7}$ \\
\hline $\mathrm{R}^{3}$ & $\mathrm{CO}_{2} \mathrm{Et}$ & $\mathrm{CF}_{3}$ \\
\hline
\end{tabular}

\begin{tabular}{ccccccc}
\hline $\mathbf{2 , 5 , 6 , 7}$ & a & b & c & d & e & f \\
\hline $\mathrm{R}$ & $\mathrm{Me}$ & $\mathrm{Me}$ & $\mathrm{Me}$ & $\mathrm{Me}$ & $\mathrm{Me}$ & $\mathrm{Me}$ \\
$\mathrm{R}^{1}$ & $\mathrm{Me}$ & $\mathrm{Ph}$ & $4-\mathrm{MeC}_{6} \mathrm{H}_{4}$ & $4-\mathrm{BrC}_{6} \mathrm{H}_{4}$ & $4-\mathrm{FC}_{6} \mathrm{H}_{4}$ & $\mathrm{H}$
\end{tabular}

\begin{tabular}{lllllll}
$\mathrm{R}^{2}$ & $\mathrm{H}$ & $\mathrm{H}$ & $\mathrm{H}$ & $\mathrm{H}$ & $\mathrm{H}$ & $\mathrm{Me}$ \\
\hline
\end{tabular}

(i) $\mathrm{NH}_{2} \mathrm{NH}_{2} \bullet \mathrm{H}_{2} \mathrm{O}$, EtOH, reflux, 5h

(ii) $\mathrm{EtO}_{2} \mathrm{CC}(\mathrm{O}) \mathrm{C}\left(\mathrm{R}^{2}\right)=\mathrm{C}\left(\mathrm{R}^{1}\right) \mathrm{OR} \quad(\mathbf{2 a - f})$ or $\mathrm{CF}_{3} \mathrm{C}(\mathrm{O}) \mathrm{C}\left(\mathrm{R}_{2}\right)=\mathrm{C}(\mathrm{OR}) \mathrm{R}^{1} \quad$ (5a-f), $\mathrm{MeOH}$ (EtOH), reflux, $16 \mathrm{~h}$

\section{Scheme 3}

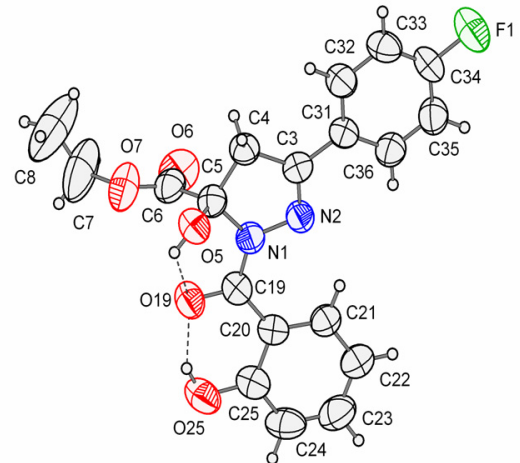

$6 e$

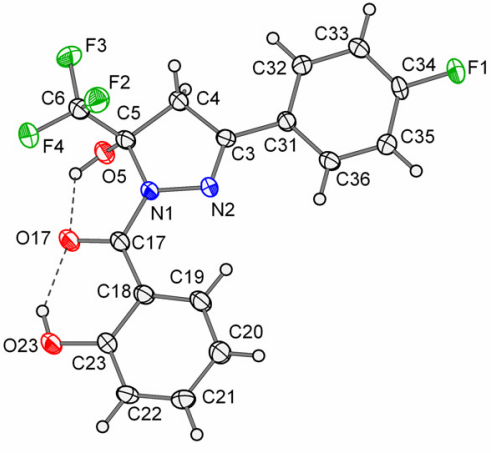

$7 e$

Figure 2. ORTEP ${ }^{18}$ obtained from crystal structure of Ethyl 3-(4-fluorophenyl)-5-hydroxy-1-(2hydroxybenzoyl)-4,5-dihydro-1H-pyrazole-5-carboxylate (6e) and 3-(4-Fluorophenyl)-5hydroxy-5-trifluoromethyl-4,5-dihydro-1H-1-(2-hydroxybenzoyl)pyrazole (7e). Displacement ellipsoids are drawn at the $50 \%$ probability level.

${ }^{1} \mathrm{H}$ and ${ }^{13} \mathrm{C}$ NMR data of compounds $6 f$ and $7 \mathbf{f}$ showed that only one pair of the diastereoisomers was obtained. Semi-empirical AM1 calculations ${ }^{21}$ showed that the diastereoisomer pair $5 S 4 R / 5 R 4 S$ were $1.95 \mathrm{kcal} \mathrm{mol}^{-1}$ (6f) and $1.52 \mathrm{kcal}^{-\mathrm{mol}^{-1}}$ (7f) more stable than the diastereoisomer pair $5 S 4 S / 5 R 4 R$. These data are supported by previously reported crystallographic studies from analogous compounds. ${ }^{22}$ The difference in energy between the two 
pairs of diastereoisomers suggests that the formation ( $>93 \%$ ) of compounds $6 \mathbf{f}$ and $7 \mathbf{f}$ supply the hydroxyl and methyl group situated cis to one another.

The structures of compounds $\mathbf{6 e}$ and $\mathbf{7 e}$ were also supported by crystal X-ray diffraction (Figure 2). These crystallographic studies confirmed the existence of hydrogen bonds involving the 2-hydroxybenzoyl moiety that was suggested from the downfield peak (broad) of the phenol proton (around $10.5 \mathrm{ppm}$ ) in the ${ }^{1} \mathrm{H}$ NMR. The intramolecular hydrogen bonds generated two six membered rings where $\mathrm{O}---\mathrm{H}$ bond distances of $1.76 \AA[\mathrm{O}(25)-\mathrm{H}(25)---\mathrm{O}(19)], 2.45 \AA[\mathrm{O}(5)$ $\mathrm{H}(5)---\mathrm{O}(19)]$ and $1.82 \AA[\mathrm{O}(23)-\mathrm{H}(23)---\mathrm{O}(17)], 2.25 \AA[\mathrm{O}(5)-\mathrm{H}(5)---\mathrm{O}(17)]$ were observed for structures $\mathbf{6 e}$ and 7e, respectively. As expected, the sum of the internal angles of the tetrasubstituted pyrazole rings $[\mathrm{N}(1)-\mathrm{N}(2)-\mathrm{C}(3)-\mathrm{C}(4)-\mathrm{C}(5)]$ suggested the planarity of this structure since values of $539.21^{\circ}$ and $539.49^{\circ}$ were found for compounds $6 \mathbf{e}$ and $7 \mathbf{e}$, respectively, deviating slightly from the ideal value of $540^{\circ}$. The crystal Data and selected bond lengths and angles are summarized and shown in Tables 1 and $2 .^{23}$

In an attempt to validate our hybridization method, the analgesic activity of compounds $\mathbf{6 a}$ and $7 \mathbf{a}$ was evaluated by the acetic acid writhing test in mice as previously described. ${ }^{24}$ In this classic test, the intraperitoneal administration of $0.8 \%$ of acetic acid $(10 \mathrm{~mL} / \mathrm{Kg})$ causes a writhing (stretching) behavior in the animal which is interpreted as its pain response.

The number of writhing responses was then counted over a period of $10 \mathrm{~min}$. In addition, the locomotor activity of the animals was evaluated on a rotarod apparatus. The compounds tested did not alter rotarod performance (data not shown) suggesting that they did not induce any form of gross motor impairment.

Oral administration of compounds 6a and 7a $(500 \mu \mathrm{mol} / \mathrm{Kg})$ caused a significant analgesic effect in the writhing test (Figure 3). This effect was similar to that obtained with the analgesic activity presented by aspirin, a classical salicylate derivative in clinical use, as no significant difference between aspirin and compounds $6 \mathbf{a}$ and $7 \mathbf{a}$ was observed. Among the 4,5-dihydro- $1 \mathrm{H}$ pyrazoles tested, the first insight obtained was that compound 7a presented better efficacy than 6a.

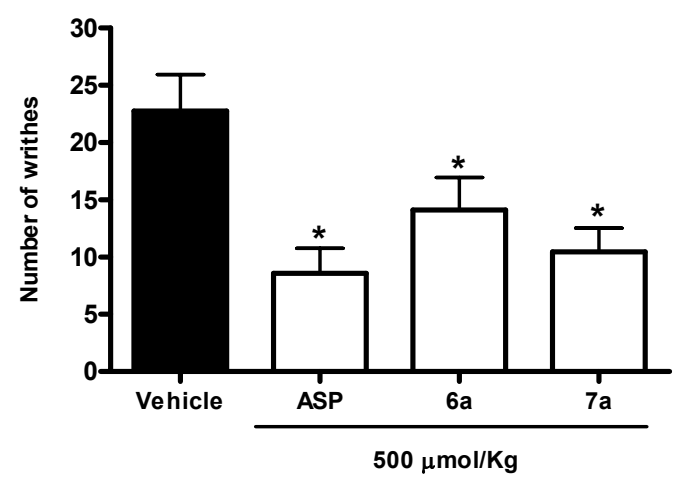

Figure 3. Effect of aspirin (ASP), 6a and 7a on the number of writhes induced by acetic acid in mice. Data are reported as means \pm S.E.M., $n=9-12$ per group. $* P<0.001[F(3,4)=6.20]$ compared with 5\% Tween 80 (Vehicle). 
Table 1. Crystallography data and refinement method for compounds $\mathbf{2 e}$, $6 \mathbf{e}$ and $\mathbf{7 e}$

\begin{tabular}{|c|c|c|c|}
\hline Crystal Data & $2 e$ & $6 e$ & $7 e$ \\
\hline $\mathrm{CCDC} \mathrm{N}^{\circ}$ & 628316 & 628318 & 628317 \\
\hline Molecular formula & $\mathrm{C}_{13} \mathrm{H}_{13} \mathrm{FO}_{4}$ & $\mathrm{C}_{19} \mathrm{H}_{17} \mathrm{~F} \mathrm{~N}_{2} \mathrm{O}_{5}$ & $\mathrm{C}_{17} \mathrm{H}_{12} \mathrm{~F}_{4} \mathrm{~N}_{2} \mathrm{O}_{3}$ \\
\hline Temperature & 294(2) K & 294(2) K & $100(2) \mathrm{K}$ \\
\hline Color & Translucent & Translucent & Translucent \\
\hline Crystal size (mm) & $0.38 \times 0.20 \times 0.08$ & $0.265 \times 0.155 \times 0.063$ & $0.34 \times 0.21 \times 0.07$ \\
\hline Symmetry & Monoclinic, $P 2(1) / \mathrm{c}$ & Triclinic, $P-1$ & Monoclinic, $P 2(1) / \mathrm{n}$ \\
\hline \multirow{6}{*}{$\begin{array}{l}\text { Unit cell dimension }(\AA \text {, } \\
\left.{ }^{\circ}\right)\end{array}$} & $a=9.6087(3) \alpha=90^{\circ}$. & $a=11.1283(3) \alpha=$ & $a=10.9400(5) \alpha=90^{\circ}$. \\
\hline & $b=15.8346(6) \beta=$ & $97.330(2)^{\circ}$. & $b=9.6633(4) \beta=$ \\
\hline & $106.352(2)^{\circ}$ & $b=13.0144(4) \beta=$ & $96.689(2)^{\circ}$. \\
\hline & \multirow[t]{3}{*}{$c=8.5386(4) \gamma=90^{\circ}$} & $109.249(2)^{\circ}$. & \multirow[t]{3}{*}{$c=14.6722(7) \gamma=90^{\circ}$} \\
\hline & & $c=14.4799(4) \gamma=$ & \\
\hline & & $108.443(2)^{\circ}$ & \\
\hline Volume $\left(\AA^{3}, Z\right)$ & $1246.60(8), 4$ & 1814.13(9), 2 & $1540.54(12), 4$ \\
\hline$D_{\mathrm{c}}\left(\mathrm{g} \cdot \mathrm{cm}^{-3}\right), F(000)$ & $1.344,528$ & $1.363,776$ & $1.588,752$ \\
\hline$\mu\left(\mathrm{mm}^{-1}\right)$ & 0.109 & 0.106 & 0.142 \\
\hline $\begin{array}{l}\theta \text { range for data } \\
\text { collection }\end{array}$ & 3.58 to $28.28^{\circ}$ & 2.10 to $28.36^{\circ}$ & 3.50 to $27.47^{\circ}$ \\
\hline Reflections collected & 13234 & 40598 & 15713 \\
\hline $\begin{array}{l}\text { Independent reflections } \\
\left(R_{\text {int }}\right)\end{array}$ & $3087(0.0302)$ & $9020(0.0599)$ & $3511(0.0408)$ \\
\hline Completeness to $\theta$ & $99.8 \%$ & $99.4 \%$ & $99.5 \%$ \\
\hline \multirow[t]{2}{*}{ Solution } & Direct methods & Direct methods & Direct methods \\
\hline & SHELXS-97 & SHELXS-97 & SHELXS-97 \\
\hline Refinement method & $\begin{array}{l}\text { Full-matrix least-squares } \\
\text { on } F^{2}\end{array}$ & $\begin{array}{l}\text { Full-matrix least-squares } \\
\text { on } F^{2}\end{array}$ & $\begin{array}{l}\text { Full-matrix least-squares } \\
\text { on } F^{2}\end{array}$ \\
\hline $\begin{array}{l}\text { Data / restraints / } \\
\text { parameters }\end{array}$ & $3087 / 12 / 185$ & $9020 / 0$ / 493 & $3511 / 0 / 235$ \\
\hline Goodness-of-fit on $F^{2}$ & 1.086 & 0.827 & 0.916 \\
\hline Final $R$ indices $[I>2 \sigma$ & $R 1=0.0446, w R 2=$ & $R 1=0.0452, w R 2=$ & $R 1=0.0387, w R 2=$ \\
\hline$(I)]$ & 0.1337 & 0.1178 & 0.0936 \\
\hline$R$ indices (all data) & $R 1=0.0756, w R 2=$ & $R 1=0.1453, w R 2=$ & $R 1=0.0671, w R 2=$ \\
\hline & 0.1441 & 0.1409 & 0.1005 \\
\hline
\end{tabular}


Table 2. Selected bond length $(\AA)$, bond angles $\left(^{\circ}\right)$ and torsional bond angles $\left(^{\circ}\right)$ for compounds 2e, 6e and 7 e

\begin{tabular}{|c|c|c|c|c|c|}
\hline \multicolumn{2}{|c|}{ Compound 2e } & \multicolumn{2}{|c|}{ Compound $\mathbf{6 e}$} & \multicolumn{2}{|c|}{ Compound 7e } \\
\hline $\mathrm{F}(1)-\mathrm{C}(15)$ & $1.366(17)$ & $\mathrm{N}(1)-\mathrm{N}(2)$ & $1.392(2)$ & $\mathrm{N}(1)-\mathrm{N}(2)$ & $1.401(17)$ \\
\hline$C(4)-C(6)$ & $1.538(2)$ & $\mathrm{N}(1)-\mathrm{C}(5)$ & $1.480(2)$ & $\mathrm{N}(1)-\mathrm{C}(5)$ & $1.491(19)$ \\
\hline$C(8)-C(9)$ & $1.354(2)$ & $\mathrm{N}(2)-\mathrm{C}(3)$ & $1.286(2)$ & $\mathrm{N}(2)-\mathrm{C}(3)$ & $1.286(18)$ \\
\hline $\mathrm{C}(6)-\mathrm{O}(7)$ & $1.2123(16)$ & $C(3)-C(4)$ & $1.501(3)$ & $C(3)-C(4)$ & $1.493(2)$ \\
\hline $\mathrm{C}(9)-\mathrm{O}(10)$ & $1.3428(17)$ & $C(4)-C(5)$ & $1.525(3)$ & $C(4)-C(5)$ & $1.535(2)$ \\
\hline $\mathrm{O}(10)-\mathrm{C}(9)-\mathrm{C}(8)$ & $122.88(13)$ & $C(5)-C(6)$ & $1.537(3)$ & $C(5)-C(6)$ & $1.537(2)$ \\
\hline $\mathrm{O}(10)-\mathrm{C}(9)-(\mathrm{C} 12)$ & $109.31(12)$ & $\mathrm{C}(5)-\mathrm{O}(5)$ & $1.395(2)$ & $\mathrm{C}(5)-\mathrm{O}(5)$ & $1.401(18)$ \\
\hline $\mathrm{O}(7)-\mathrm{C}(6)-\mathrm{C}(8)$ & $128.12(14)$ & $\mathrm{N}(2)-\mathrm{N}(1)-\mathrm{C}(5)$ & $112.83(16)$ & $\mathrm{N}(2)-\mathrm{N}(1)-\mathrm{C}(5)$ & $111.79(11)$ \\
\hline$C(9)-C(8)-C(6)$ & $126.42(13)$ & $\mathrm{C}(3)-\mathrm{N}(2)-\mathrm{N}(1)$ & $107.83(16)$ & $\mathrm{C}(3)-\mathrm{N}(2)-\mathrm{N}(1)$ & $108.52(12)$ \\
\hline $\mathrm{O}(7)-\mathrm{C}(6)-\mathrm{C}(4)$ & $118.01(13)$ & $\mathrm{N}(2)-\mathrm{C}(3)-\mathrm{C}(4)$ & $114.12(18)$ & $\mathrm{N}(2)-\mathrm{C}(3)-\mathrm{C}(4)$ & $114.37(14)$ \\
\hline $\mathrm{O}(5)-\mathrm{C}(4)-\mathrm{C}(6)$ & $124.06(14)$ & $C(3)-C(4)-C(5)$ & $103.01(16)$ & $C(3)-C(4)-C(5)$ & $103.07(12)$ \\
\hline $\mathrm{O}(5)-\mathrm{C}(4)-\mathrm{O}(3)$ & $123.8(3)$ & $\mathrm{N}(1)-\mathrm{C}(5)-\mathrm{C}(4)$ & $101.42(15)$ & $\mathrm{N}(1)-\mathrm{C}(5)-\mathrm{C}(4)$ & $101.74(12)$ \\
\hline $\begin{array}{l}C(8)-C(9)-C(12)- \\
C(17)\end{array}$ & $-52.0(2)$ & $\begin{array}{l}\mathrm{O}(19)-\mathrm{C}(19)-\mathrm{N}(1)- \\
\mathrm{N}(2)\end{array}$ & $177.65(17)$ & $\begin{array}{l}\mathrm{N}(2)-\mathrm{N}(1)-\mathrm{C}(17)- \\
\mathrm{O}(17)\end{array}$ & $\begin{array}{l}- \\
165.49(14)\end{array}$ \\
\hline $\begin{array}{l}\mathrm{O}(5)-\mathrm{C}(4)-\mathrm{C}(6)- \\
\mathrm{O}(7)\end{array}$ & $\begin{array}{l}- \\
170.02(17)\end{array}$ & $\begin{array}{l}\mathrm{C}(21)-\mathrm{C}(20)-\mathrm{C}(19)- \\
\mathrm{N}(1)\end{array}$ & $-4.0(3)$ & $\begin{array}{l}N(1)-C(17)-C(18)- \\
C(19)\end{array}$ & $-3.7(3)$ \\
\hline $\begin{array}{l}\mathrm{O}(10)-\mathrm{C}(9)-\mathrm{C}(12)- \\
\mathrm{C}(13)\end{array}$ & $-47.35(18)$ & $\begin{array}{l}\mathrm{N}(2)-\mathrm{C}(3)-\mathrm{C}(31)- \\
\mathrm{C}(36)\end{array}$ & $5.9(3)$ & $\begin{array}{l}\mathrm{N}(2)-\mathrm{C}(3)-\mathrm{C}(31)- \\
\mathrm{C}(36)\end{array}$ & $8.8(2)$ \\
\hline
\end{tabular}

In summary, a simple and efficient method for the synthesis of 4-alkoxy-2-oxo-3-butenoic esters was reported. Regiospecific cyclocondensation of these substrates and their trifluoromethylated analogues with salicylic hydrazide led to the 4,5-dihydro- $1 H$-pyrazole derivatives in good yields. In addition, the structures of these series of compounds were also supported by crystallographic studies. The hybridized compounds $\mathbf{6 a}$ and $7 \mathbf{a}$ showed interesting analgesic activity in mice, validating this design for the construction of novel analgesic agents. Further investigations are in progress to elucidate the structural requirements for the analgesic effect of this class of compounds, as well as their action on other models of pain. Finally, our preliminary findings showed the synthesized 4,5-dihydro- $1 H$-pyrazole derivatives as promising prototypes for the treatment of states of pain. 


\section{Experimental Section}

General Procedures. Unless otherwise indicated, all common reagents were used as obtained from commercial suppliers without further purification. The solvents were dried and purified according to recommended procedures. ${ }^{25}$ All melting points were measured using a ReichertThermovar apparatus and are uncorrected. Yields listed are of isolated compounds.

${ }^{1} \mathrm{H}$ and ${ }^{13} \mathrm{C}$ NMR spectra were acquired on a Bruker DPX 200 or Bruker DPX 400 spectrometer $\left({ }^{1} \mathrm{H}\right.$ at $200.13 \mathrm{MHz}$ or $400.13 \mathrm{MHz}$ and ${ }^{13} \mathrm{C}$ at $50.32 \mathrm{MHz}$ or $100.63 \mathrm{MHz}$, respectively) at 300 $\mathrm{K}$, in $5 \mathrm{~mm}$ sample tubes, and with a digital resolution of $\pm 0.01 \mathrm{ppm} . \mathrm{CDCl}_{3}$, or DMSO- $d 6$ were used as solvents containing TMS as internal standard. Mass spectra were registered in a HP 5973 MSD connected to a HP 6890 GC and interfaced by a Pentium PC. The GC was equipped with a split-splitless injector, autosampler cross-linked HP-5 capillary column $(30 \mathrm{~m}, 0.32 \mathrm{~mm}$ of internal diameter), and helium was used as the carrier gas. IR spectra were obtained with a Bruker Tensor 27 spectrometer using films or $\mathrm{KBr}$ pellets of the compounds. The crystal data were recorded on a Bruker Kappa Apex II CCD area detector with graphite monochromatized Mo $\mathrm{K}_{\alpha}$ radiation $(\lambda=0.71073 \AA)$. The data were processed with SAINT and SADABS. The structure was solved by direct methods (SHELXS-97) and additional atoms were located in the difference Fourier map and refined on F2 (SHELXL-97) using the SHELXTL ${ }^{26}$ and Wingx ${ }^{27}$ packages. The $\mathrm{CHN}$ elemental analyses were performed on a Perkin-Elmer $2400 \mathrm{CHN}$ elemental analyzer (Federal University of Rio Grande do Sul, UFRGS/ Brazil). Statistical treatments of analgesic data were carried out by one-way ANOVA followed by Student-Newman-Keuls test.

\section{General procedure for synthesis of 4-alkoxy-2-oxo-but(pent)-3-enoic acid ethyl esters 2a,f} To a stirred solution of ethyl oxalyl chloride $(2.34 \mathrm{ml}, 21 \mathrm{mmol})$ in dry $\mathrm{CHCl}_{3}(20 \mathrm{~mL})$ at $0^{\circ} \mathrm{C}$, a solution of enol ether $1(20 \mathrm{mmol}), \mathrm{CHCl}_{3}(15 \mathrm{~mL})$ and pyridine $(1.7 \mathrm{ml}, 21 \mathrm{mmol})$ was added dropwise. The mixture was left to cool for at least $2 \mathrm{~h}$ and then was allowed to gradually warm to room temperature and then stirred for $16 \mathrm{~h}$ to afford the compounds $2 \mathrm{f}$. The acylation of metoxypropene $(\mathbf{1 b})$ required heating at $35^{\circ} \mathrm{C}$ for $18 \mathrm{~h}$. After this time, the mixture was washed with a solution of $\mathrm{H}_{2} \mathrm{O}: \mathrm{HCl}(10: 1)(2 \times 10 \mathrm{~mL})$, and with distilled water $(2 \times 10 \mathrm{~mL})$. The crude products $(\mathbf{2 a}, \mathbf{f})$ were obtained with satisfactory purity and were used without additional purification.

\section{General procedure for synthesis of $(E)$-4-aryl-4-methoxy-2-oxo-but-3-enoic acid ethyl esters 2b-e}

To a stirred solution of ethyl oxalyl chloride $(4.6 \mathrm{ml}, 41 \mathrm{mmol})$ in dry $\mathrm{CHCl}_{3}(25 \mathrm{~mL})$ at $0^{\circ} \mathrm{C}$, a solution containing the acetal $1(20 \mathrm{mmol}), \mathrm{CHCl}_{3}(15 \mathrm{~mL})$ and pyridine $(3.25 \mathrm{ml}, 41 \mathrm{mmol})$ was added dropwise. The mixture was left to cool for at least $1 \mathrm{~h}$, then was allowed to warm to room temperature and refluxed for $5 \mathrm{~h}$. The remaining workup was done as already described for compounds 2a,f. After the solvent had evaporated the residue was distilled under vacuum to 
afford product 2 . The methyl ethyl oxalylate formed during the course of the reaction was distilled at $50{ }^{\circ} \mathrm{C}(6.2 \mathrm{mbar})$.

(E)-4-Methoxy-2-oxo-pent-3-enoic acid ethyl ester (2a). Yield: $18.4 \mathrm{mmol}$ (92\%); oil; For IR ${ }^{1} \mathrm{H}$ and ${ }^{13} \mathrm{C}$ NMR and MS data see ref. 11b. Anal. Calcd. for $\mathrm{C}_{8} \mathrm{H}_{12} \mathrm{O}_{4}$ : C, 55.81; H, 7.02 . Found: C, 55.67; H, 6.88 .

(E)-4-Methoxy-2-oxo-4-phenyl-but-3-enoic acid ethyl ester (2b). Yield: $16.0 \mathrm{mmol}(80 \%)$; bp $169-171^{\circ} \mathrm{C}$ (6.0 mbar); IR (film, $v, \mathrm{~cm}^{-1}$ ): 2984, 1732, 1684, 1646, 1285, 1190, 1081, 765; ${ }^{1} \mathrm{H}$ NMR (200 MHz, CDCl $\left.)_{3}\right): \delta 1.24\left(\mathrm{t}, 3 \mathrm{H}, \mathrm{O}-\mathrm{C}-\mathrm{CH}_{3}\right), 3.94\left(\mathrm{~s}, 3 \mathrm{H}, \mathrm{O}-\mathrm{CH}_{3}\right), 4.04\left(\mathrm{q}, 2 \mathrm{H}, \mathrm{O}-\mathrm{CH}_{2}\right.$ ), 6.17 (s, 1H, H-3), 7.33-7.48 (m, 5H, Ph); $\left.{ }^{13} \mathrm{C} \mathrm{NMR} \mathrm{(50} \mathrm{MHz,} \mathrm{CDCl}_{3}\right): \delta 13.5\left(\mathrm{O}-\mathrm{C}-\mathrm{CH}_{3}\right), 56.8$ $\left(\mathrm{O}-\mathrm{CH}_{3}\right), 61.6\left(\mathrm{O}-\mathrm{CH}_{2}\right), 96.9(\mathrm{C}-3), 127.6,128.8,130.5,133.9(\mathrm{Ph}), 163.2(\mathrm{C}-1), 175.5(\mathrm{C}-4)$, 181.8 (C-2); MS: $m / z \%=234\left(\mathrm{M}^{+}, 1\right), 161$ (100), 131 (9), 115 (79), 105 (54), 77 (76), 59 (56); Anal. Calcd. for $\mathrm{C}_{13} \mathrm{H}_{14} \mathrm{O}_{4}$ : C, 66.66; H, 6.02. Found: C, 66.35; H, 5.59.

(E)-4-(4-Methylphenyl)-4-methoxy-2-oxo-but-3-enoic acid ethyl ester (2c). Yield: $14.0 \mathrm{mmol}$ (70\%); bp 180-182 ${ }^{\circ} \mathrm{C}$ (6.0 mbar); IR (KBr, v, cm $\left.{ }^{-1}\right): 3056,1728,1680,1629,1588,1273,1197$, 747; ${ }^{1} \mathrm{H}$ NMR $\left(200 \mathrm{MHz}, \mathrm{CDCl}_{3}\right): \delta 1.24\left(\mathrm{t}, 3 \mathrm{H}, \mathrm{O}-\mathrm{C}-\mathrm{CH}_{3}\right), 2.37\left(\mathrm{~s}, 3 \mathrm{H}, 4-\mathrm{Me}-\mathrm{C}_{6} \mathrm{H}_{4}\right), 3.92(\mathrm{~s}$, $\left.3 \mathrm{H}, \mathrm{O}-\mathrm{CH}_{3}\right), 4.04\left(\mathrm{q}, 2 \mathrm{H}, \mathrm{O}-\mathrm{CH}_{2}\right), 6.13(\mathrm{~s}, 1 \mathrm{H}, \mathrm{H}-3), 7.18-7.38\left(\mathrm{~m}, 4 \mathrm{H}, \mathrm{C}_{6} \mathrm{H}_{4}\right) ;{ }^{13} \mathrm{C}$ NMR $(50$ $\left.\mathrm{MHz}, \mathrm{CDCl}_{3}\right): \delta 13.4\left(\mathrm{O}-\mathrm{C}-\mathrm{CH}_{3}\right), 21.0\left(4-\mathrm{Me}-\mathrm{C}_{6} \mathrm{H}_{5}\right), 56.6\left(\mathrm{O}-\mathrm{CH}_{3}\right), 61.5\left(\mathrm{O}-\mathrm{CH}_{2}\right), 96.6(\mathrm{C}-3)$, 128.2, 128.8, 130.9, $\left.140.9\left(\mathrm{C}_{6} \mathrm{H}_{4}\right), 163.2(\mathrm{C}-1), 175.6(\mathrm{C}-4), 181.8 \mathrm{C}-2\right)$; MS: $m / z \%=248\left(\mathrm{M}^{+}\right.$, 1), 175 (100), 132 (12), 115 (75), 91 (78), 59 (39); Anal. Calcd. for $\mathrm{C}_{14} \mathrm{H}_{16} \mathrm{O}_{4}$ : C, 67.73; $\mathrm{H} 6.50$. Found: C, 67.41; H, 6.36.

(E)-4-(4-Bromophenyl)-4-methoxy-2-oxo-but-3-enoic acid ethyl ester (2d). Yield: 12.4 mmol $(62 \%) ; \mathrm{mp} 68-70^{\circ} \mathrm{C}$; bp 196-198 ${ }^{\circ} \mathrm{C}(5.9 \mathrm{mbar})$; IR (KBr, v, $\left.\mathrm{cm}^{-1}\right): 2993,1719,1674,1549,1293$, 1141, 1080, 764; ${ }^{1} \mathrm{H}$ NMR (200 MHz, $\left.\mathrm{CDCl}_{3}\right): \delta(\mathrm{J}, \mathrm{Hz}) 1.30\left(\mathrm{t}, 3 \mathrm{H}, \mathrm{O}-\mathrm{C}-\mathrm{CH}_{3}\right), 3.94$ (s, 3H, O$\left.\mathrm{CH}_{3}\right), 4.16\left(\mathrm{q}, 2 \mathrm{H}, \mathrm{O}-\mathrm{CH}_{2}\right), 6.28(\mathrm{~s}, 1 \mathrm{H}, \mathrm{H}-3), 7.35\left(\mathrm{~d}, 2 \mathrm{H}, J=9, \mathrm{C}_{6} \mathrm{H}_{4}\right), 7.52(\mathrm{~d}, 2 \mathrm{H}, J=9$, $\left.\mathrm{C}_{6} \mathrm{H}_{4}\right) ;{ }^{13} \mathrm{C}$ NMR $\left(50 \mathrm{MHz}, \mathrm{CDCl}_{3}\right): \delta 13.7\left(\mathrm{O}-\mathrm{C}-\mathrm{CH}_{3}\right), 57.0\left(\mathrm{O}-\mathrm{CH}_{3}\right), 62.0\left(\mathrm{O}-\mathrm{CH}_{2}\right), 96.5(\mathrm{C}-3)$, 125.1, 130.5, 130.9, $132.8\left(\mathrm{C}_{6} \mathrm{H}_{4}\right), 163.0(\mathrm{C}-1), 174.3$ (C-4), 180.7 (C-2); MS: $m / z \%=314$ $\left(\mathrm{M}^{+} 2,1\right), 241$ (100), 183 (43), 160 (30), 116 (82), 89 (88), 59 (90); Anal. Calcd. for $\mathrm{C}_{13} \mathrm{H}_{13} \mathrm{BrO}_{4}$ : C, 49.86; H 4.18. Found: C, 49.60; H, 3.91.

(E)-4-(4-Fluorophenyl)-4-methoxy-2-oxo-but-3-enoic acid ethyl ester (2e). Yield: 16.8 mmol (84\%); mp 45-47 C; bp 174-176 ${ }^{\circ} \mathrm{C}(6.8 \mathrm{mbar})$; IR (KBr, v, $\left.\mathrm{cm}^{-1}\right): 2984,1721,1675,1282,1226$, 1081, 774; ${ }^{1} \mathrm{H}$ NMR (200 MHz, $\left.\mathrm{CDCl}_{3}\right): \delta 1.29$ (t, 3H, O-C-CH$), 3.94$ (s, 3H, O-CH $), 4.15$ (q, $\left.2 \mathrm{H}, \mathrm{O}-\mathrm{CH}_{2}\right), 6.26(\mathrm{~s}, 1 \mathrm{H}, \mathrm{H}-3), 7.02-7.54\left(\mathrm{~m}, 4 \mathrm{H}, \mathrm{C}_{6} \mathrm{H}_{4}\right) ;{ }^{13} \mathrm{C} \mathrm{NMR}\left(50 \mathrm{MHz}, \mathrm{CDCl}_{3}\right): \delta\left(J_{\mathrm{C}-\mathrm{F}}\right.$, $\mathrm{Hz}) 13.5\left(\mathrm{O}-\mathrm{C}-\mathrm{CH}_{3}\right), 56.8\left(\mathrm{O}-\mathrm{CH}_{3}\right), 61.8\left(\mathrm{O}-\mathrm{CH}_{2}\right), 96.2(\mathrm{C}-3), 114.6\left(\mathrm{~d},{ }^{2} J=22, \mathrm{C}_{6} \mathrm{H}_{4}\right), 129.8(\mathrm{~d}$, $\left.{ }^{4} J=3, \mathrm{C}_{6} \mathrm{H}_{4}\right), 131.2\left(\mathrm{~d},{ }^{3} J=9, \mathrm{C}_{6} \mathrm{H}_{4}\right), 163.0(\mathrm{C}-1), 163.8\left(\mathrm{~d},{ }^{1} J=251, \mathrm{C}_{6} \mathrm{H}_{4}\right), 174.3(\mathrm{C}-4), 180.7$ (C-2); MS: $m / z \%=252\left(\mathrm{M}^{+}, 1\right), 179$ (100), 149 (9), 133 (33), 123 (58), 95 (48), 59 (76); Anal. Calcd. for $\mathrm{C}_{13} \mathrm{H}_{13} \mathrm{FO}_{4}$ : C, 61.90; H, 5.19. Found: C, 61.60; H, 4.98.

(E)-4-Ethoxy-3-methyl-2-oxo-but-3-enoic acid ethyl ester (2f). Yield: $13.6 \mathrm{mmol}$ (68\%); oil; IR (film, v, cm ${ }^{-1}$ ): 2985, 1735, 1625, 1218, 1050, 1016, 720; ${ }^{1} \mathrm{H} \mathrm{NMR}\left(200 \mathrm{MHz}, \mathrm{CDCl}_{3}\right): \delta 1.37$ (t, 3H, O-C-CH $)_{3}, 1.38$ (t, 3H, R $\left.{ }^{2}\right), 1.93\left(\mathrm{~s}, 3 \mathrm{H}, \mathrm{CH}_{3}\right), 4.19$ (q, 2H, O-CH $\mathrm{CH}_{2}, 4.33$ (q, 2H, O-CH $)$, $7.59(\mathrm{~s}, 1 \mathrm{H}, \mathrm{H}-3){ }^{13} \mathrm{C} \mathrm{NMR}\left(50 \mathrm{MHz}, \mathrm{CDCl}_{3}\right): \delta 7.1\left(\mathrm{R}^{2}\right), 13.6\left(\mathrm{CH}_{3}\right.$, ethyl ester), $15.0\left(\mathrm{CH}_{3}\right.$, 
ethoxy), $61.7\left(\mathrm{OCH}_{2}\right.$, ethyl ester), $71.2\left(\mathrm{OCH}_{2}\right.$, ethoxy), $127.0(\mathrm{C}-3), 164.0(\mathrm{C}-1), 165.8(\mathrm{C}-4)$, 186.2 (C-2); MS: $m / z \%=186\left(\mathrm{M}^{+}, 1\right), 113$ (54), 85 (100), 55 (17); Anal. Calcd. for $\mathrm{C}_{9} \mathrm{H}_{14} \mathrm{O}_{4}$ : C, 58.05; H, 7.58. Found: C, 57.76; H, 7.55.

\section{General procedure for synthesis of 5-Hydroxy-4,5-dihydro-1H-pyrazoles 6a-f, 7a-f}

A mixture of 4-alkoxy-4-alkyl(aryl)-2-oxo-but-3-enoic acid ethyl esters 2 (5 mmol) or 4-alkoxy4-alkyl(aryl)-1,1,1-trifluoro-3-buten-2-ones 5 (5 mmol) and salicylic hydrazide 4 (912 $\mathrm{mg}, 6$ mmol) was stirred under reflux in dry methanol or ethanol $(30 \mathrm{~mL})$ for $16 \mathrm{~h}$. After the mixture was cooled to room temperature the mixture was diluted with water $(20 \mathrm{~mL})$ and extracted with $\mathrm{CH}_{2} \mathrm{Cl}_{2}(3 \times 30 \mathrm{~mL})$. The combined organic layers were dried over $\mathrm{Na}_{2} \mathrm{SO}_{4}$, and evaporated under vacuum. Recrystallization from a mixture of hexane/EtOAc (10:1) afforded the pure 5hydroxy-4,5-dihydro-1H-pyrazoles $\mathbf{6}, 7$.

Ethyl 5-hydroxy-3-methyl-1-(2-hydroxybenzoyl)-4,5-dihydro-1 H-pyrazole-5-carboxylate (6a). Yield: $3.25 \mathrm{mmol}(65 \%)$; mp 124-126 ${ }^{\circ} \mathrm{C}$; ${ }^{1} \mathrm{H}$ NMR $\left(200 \mathrm{MHz}, \mathrm{CDCl}_{3}\right): \delta(\mathrm{J}, \mathrm{Hz}) 1.28(\mathrm{t}$, $\left.3 \mathrm{H}, \mathrm{O}-\mathrm{C}-\mathrm{CH}_{3}\right), 2.16$ (s, 3H, R ${ }^{1}$ ), 2.97 (d, 1H, $\left.J=18, \mathrm{H}-4 \mathrm{a}\right), 3.20$ (d, 1H, $\left.J=18, \mathrm{H}-4 \mathrm{~b}\right), 4.27-4.40$ (m, 2H, O-CH2), 6.83-6.98 (m, 2H, Benzoyl), 7.36-7.44 (m, 1H, Benzoyl), 8.43-8.47 (m, 1H, Benzoyl); ${ }^{13} \mathrm{C}$ NMR (50 MHz, DMSO-d6): $\delta 13.9\left(\mathrm{CH}_{3}\right), 15.4\left(\mathrm{R}^{1}\right), 49.4(\mathrm{C}-4), 61.3\left(\mathrm{OCH}_{2}\right)$, 88.0 (C-5), 116.2, 118.2, 120.7, 129.1, 131.5, 155.4 (Benzoyl), 156.3 (C=O, Benzoyl), 165.2 $\left(\mathrm{CO}_{2} \mathrm{Et}\right), 169.3$ (C-3); MS: $m / z \%=292\left(\mathrm{M}^{+}, 14\right), 219$ (11), 201 (77), 177 (15), 121 (100), 99 (98), 65 (51); Anal. Calcd. for $\mathrm{C}_{14} \mathrm{H}_{16} \mathrm{~N}_{2} \mathrm{O}_{5}$ : C, 57.53; H, 5.52; N, 9.58. Found: C, 57.14; H, 5.17; N, 9.75 .

Ethyl 5-hydroxy-3-phenyl-1-(2-hydroxybenzoyl)-4,5-dihydro-1 $H$-pyrazole-5-caboxylate (6b). Yield: $3.9 \mathrm{mmol}(78 \%)$; mp 109-111 ${ }^{\circ} \mathrm{C}$; ${ }^{1} \mathrm{H}$ NMR $\left(200 \mathrm{MHz}, \mathrm{CDCl}_{3}\right): \delta(J, \mathrm{~Hz}) 1.29$ (t, 3H, O-C-CH C $_{3} 3.44$ (d, 1H, $\left.J=18, \mathrm{H}-4 \mathrm{a}\right), 3.60$ (d, 1H, $\left.J=18, \mathrm{H}-4 \mathrm{~b}\right), 4.29-4.42$ (m, 2H, O-CH $)$, 6.93-7.01 (m, 2H, Benzoyl), 7.43-7.50 (m, 5H, Ph), 7.75-7.78 (m, 1H, Benzoyl), 8.60-8.63 (m, 1H, Benzoyl), 11.48 (s, 1H, 2-OH-Benzoyl); ${ }^{13} \mathrm{C}$ NMR (50 MHz, DMSO-d6): $\delta 13.9\left(\mathrm{CH}_{3}\right), 45.9$ (C4), $61.5\left(\mathrm{OCH}_{2}\right), 88.6$ (C5), 116.3, 118.3, 120.3, 131.9, 153.1 (Benzoyl), 126.6, 128.8, 129.5, $130.5(\mathrm{Ph}), 156.7(\mathrm{C} 3), 165.7\left(\mathrm{C}=\mathrm{O}\right.$, Benzoyl), $169.1\left(\mathrm{CO}_{2} \mathrm{Et}\right) ; \mathrm{MS}: m / z \%=354\left(\mathrm{M}^{+}, 6\right), 281$ (6), 263 (18), 161 (100), 121 (63), 65 (20); Anal. Calcd. for $\mathrm{C}_{19} \mathrm{H}_{18} \mathrm{~N}_{2} \mathrm{O}_{5}$ : C, 64.40; H, 5.12; N, 7.91. Found: C, 64.34; H, 5.09; N, 7.74.

Ethyl 5-hydroxy-3-(4-methylphenyl)-1-(2-hydroxybenzoyl)-4,5-dihydro-1H-pyrazole-5carboxylate (6c). Yield: $3.65 \mathrm{mmol}(73 \%)$; mp 116-118 ${ }^{\circ} \mathrm{C} ;{ }^{1} \mathrm{H} \mathrm{NMR}\left(200 \mathrm{MHz}, \mathrm{CDCl}_{3}\right): \delta(J$, Hz) 1.29 (t, 3H, O-C-CH $), 2.42\left(\mathrm{~s}, 3 \mathrm{H}, 4-\mathrm{CH}_{3}-\mathrm{C}_{6} \mathrm{H}_{5}\right), 3.41(\mathrm{~d}, 1 \mathrm{H}, J=18, \mathrm{H} 4 \mathrm{a}), 3.59(\mathrm{~d}, 1 \mathrm{H}, J=$ 18, H-4b), 4.26-4.46 (m, 2H, $\left.\mathrm{OCH}_{2}\right)$, 6.90-7.02 (m, 2H, Benzoyl), 7.24-7.28 (m, 2H, $\left.\mathrm{C}_{6} \mathrm{H}_{4}\right)$, 7.40-7.48 (m, 1H, Benzoyl), $7.64\left(\mathrm{~m}, 2 \mathrm{H}, \mathrm{C}_{6} \mathrm{H}_{4}\right), 8.60-8.64\left(\mathrm{~m}, 1 \mathrm{H}\right.$, Benzoyl); ${ }^{13} \mathrm{C}$ NMR (50 MHz, DMSO-d6): $\delta 13.8\left(\mathrm{O}-\mathrm{C}-\mathrm{CH}_{3}\right), 21.0\left(4-\mathrm{CH}_{3}-\mathrm{C}_{6} \mathrm{H}_{4}\right), 45.9(\mathrm{C}-4), 61.5\left(\mathrm{O}-\mathrm{CH}_{2}\right), 88.6(\mathrm{C}-5)$, 116.3, 118.3, 120.2, 129.3, 132.0, 153.2 (Benzoyl), 126.6, 127.7, 129.6, $140.4\left(\mathrm{C}_{6} \mathrm{H}_{4}\right), 156.9(\mathrm{C}-$ 3), $165.7\left(\mathrm{C}=\mathrm{O}\right.$, Benzoyl), $169.1\left(\mathrm{CO}_{2} \mathrm{Et}\right)$; MS: $m / z \%=368\left(\mathrm{M}^{+}, 5\right), 248$ (6), 230 (7), 179 (15), 121 (100), 101 (8), 65 (28); Anal. Calcd. for $\mathrm{C}_{20} \mathrm{H}_{20} \mathrm{~N}_{2} \mathrm{O}_{5}$ : C, 65.21; H, 5.47; N 7.60. Found: C, 64.84; H, 5.44; N, 7.56. 
Ethyl 3-(4-bromophenyl)-5-hydroxy-1-(2-hydroxybenzoyl)-4,5-dihydro-1 $H$-pyrazole-5carboxylate (6d). Yield: $4.45 \mathrm{mmol}(89 \%)$; mp 138-140 ${ }^{\circ} \mathrm{C} ;{ }^{1} \mathrm{H}$ NMR $\left(200 \mathrm{MHz}, \mathrm{CDCl}_{3}\right): \delta(J$, Hz) 1.29 (t, 3H, O-C-CH $), 3.39$ (d, $1 \mathrm{H}, J=18, \mathrm{H}-4 \mathrm{a}), 3.58$ (d, 1H, $J=18, \mathrm{H}-4 \mathrm{~b}), 4.26-4.47$ (m, 2H, O-CH 2 ), 6.88-7.04 (m, 2H, Benzoyl), 7.41-7.49 (m, 1H, Benzoyl), 7.60 (m, 4H, $\left.\mathrm{C}_{6} \mathrm{H}_{4}\right), 8.52-$ 8.57 (m, 1H, Benzoyl); ${ }^{13} \mathrm{C}$ NMR (50 MHz, DMSO-d6): $\delta 13.9\left(\mathrm{O}-\mathrm{C}-\mathrm{CH}_{3}\right), 45.8(\mathrm{C}-4), 61.6(\mathrm{O}-$ $\mathrm{CH}_{2}$ ), 88.7 (C-5), 116.3, 118.3, 120.6, 129.3, 129.7, 152.1 (Benzoyl), 123.9, 128.3, 128.5, 131.8 $\left(\mathrm{C}_{6} \mathrm{H}_{4}\right), 156.4(\mathrm{C}-3), 165.8\left(\mathrm{C}=\mathrm{O}\right.$, Benzoyl), $169.0\left(\mathrm{CO}_{2} \mathrm{Et}\right) ; \mathrm{MS}: m / z \%=434\left(\mathrm{M}^{+} 2,4\right), 361$ (5), 341 (7), 314 (9), 241 (40), 121 (100), 93 (21), 65 (40); Anal. Calcd. for $\mathrm{C}_{19} \mathrm{H}_{17} \mathrm{BrN}_{2} \mathrm{O}_{5}$ : C, 52.68; H, 3.96; N, 6.47. Found: C, 52.45; H, 3.94; N, 6.44.

Ethyl 3-(4-fluorophenyl)-5-hydroxy-1-(2-hydroxy benzoyl)-4,5-dihydro-1 $H$-pyrazole-5carboxylate (6e). Yield: $4.25 \mathrm{mmol}(85 \%)$; mp 128-130 ${ }^{\circ} \mathrm{C} ;{ }^{1} \mathrm{H} \mathrm{NMR}\left(200 \mathrm{MHz}, \mathrm{CDCl}_{3}\right): \delta(J$, Hz) 1.29 (t, 3H, O-C-CH $), 3.40$ (d, $1 \mathrm{H}, J=18, \mathrm{H}-4 \mathrm{a}), 3.59$ (d, 1H, $J=18, \mathrm{H}-4 \mathrm{~b}), 4.23-4.47$ (m, 2H, O- $\mathrm{CH}_{2}$ ), 6.91-7.01 (m, 2H, Benzoyl), 7.11-7.20 (m, 2H, $\left.\mathrm{C}_{6} \mathrm{H}_{4}\right), 7.40-7.49$ (m, 1H, Benzoyl), 7.72-7.79 (m, 2H, $\left.\mathrm{C}_{6} \mathrm{H}_{4}\right), 8.54-8.58\left(\mathrm{~m}, 1 \mathrm{H}\right.$, Benzoyl); ${ }^{13} \mathrm{C}$ NMR $(100 \mathrm{MHz}, \mathrm{DMSO}-d 6): \delta\left(J_{\mathrm{C}-\mathrm{F}}\right.$, Hz) $13.9\left(\mathrm{CH}_{3}\right), 46.0(\mathrm{C}-4), 61.6\left(\mathrm{OCH}_{2}\right), 88.7(\mathrm{C}-5), 115.9\left(\mathrm{~d},{ }^{2} J=22, \mathrm{C}_{6} \mathrm{H}_{4}\right), 127.2\left(\mathrm{~d},{ }^{4} J=3\right)$, $129.0\left(\mathrm{~d},{ }^{3} J=8\right), 163.3\left(\mathrm{~d},{ }^{1} J=248\right), 116.3,118.3,120.6,129.6,131.9,152.2$ (Benzoyl), 156.5 (C-3), 165.8 (C=O, Benzoyl), $169.1\left(\mathrm{CO}_{2} \mathrm{Et}\right)$; MS: $m / z \%=372\left(\mathrm{M}^{+}, 10\right), 299$ (10), 281 (25), 252 (24), 179 (100), 121 (100), 93 (33), 65 (65); Anal. Calcd. for $\mathrm{C}_{19} \mathrm{H}_{17} \mathrm{FN}_{2} \mathrm{O}_{5}$ : C, 61.29; $\mathrm{H}$, 4.60; N, 7.52. Found: C, 61.31; H, 4.42; N, 7.43.

Ethyl 5-Hydroxy-4-methyl-1-(2-hydroxybenzoyl)-4,5-dihydro-1 $H$-pyrazole-5-carboxylate (6f). Yield: $3.0 \mathrm{mmol}(60 \%)$; $\mathrm{mp} 88-90^{\circ} \mathrm{C} ;{ }^{1} \mathrm{H} \mathrm{NMR}\left(200 \mathrm{MHz}, \mathrm{CDCl}_{3}\right): \delta(J, \mathrm{~Hz}) 1.22-1.42(\mathrm{~m}$, $\left.3 \mathrm{H}, \mathrm{O}-\mathrm{C}-\mathrm{CH}_{3}\right), 1.30\left(\mathrm{~d}, 3 \mathrm{H}, J=7, \mathrm{R}^{2}\right), 3.41$ (qd, $\left.J=7, J=1, \mathrm{H}-4\right), 4.25-4.44\left(\mathrm{~m}, 2 \mathrm{H}, \mathrm{OCH}_{2}\right)$, 6.87 (qd, $J=7, J=1,1 \mathrm{H}, \mathrm{H}-3$ ), 6.95-6.99 (m, 2H, Benzoyl), 7.37-7.45 (m, 1H, Benzoyl), 8.338.38 (m, 1H, Benzoyl); ${ }^{13} \mathrm{C}$ NMR (50 MHz, DMSO-d6): $\delta 8.9\left(\mathrm{R}^{2}\right), 13.9\left(\mathrm{O}-\mathrm{C}-\mathrm{CH}_{3}\right), 50.0(\mathrm{C}-4)$, 61.5 (O-CH2), 87.5 (C-5), 116.1, 118.2, 121.3, 129.0, 131.4, 151.1 (Benzoyl), 155.8 (C-3), 166.0 $\left(\mathrm{C}=\mathrm{O}\right.$, Benzoyl), $167.9\left(\mathrm{CO}_{2} \mathrm{Et}\right) ; \mathrm{MS}: m / z \%=292\left(\mathrm{M}^{+}, 10\right), 219$ (13), 201 (71), 163 (38), 121 (100), 93 (58), 65 (100); Anal. Calcd. for $\mathrm{C}_{14} \mathrm{H}_{16} \mathrm{~N}_{2} \mathrm{O}_{5}$ : C, 57.53; H, 5.52; N, 9.58. Found: C, $57.68 ; \mathrm{H}, 5.84 ; \mathrm{N}, 9.69$.

5-Hydroxy-3-methyl-5-trifluoromethyl-4,5-dihydro-1H-1-(2-hydroxybenzoyl)pyrazole (7a). Yield: $4.5 \mathrm{mmol}(90 \%)$; mp 74-76 ${ }^{\circ} \mathrm{C} ;{ }^{1} \mathrm{H} \mathrm{NMR}\left(200 \mathrm{MHz}, \mathrm{CDCl}_{3}\right): \delta(J, \mathrm{~Hz}) 2.11\left(\mathrm{~s}, 3 \mathrm{H}, \mathrm{R}^{1}\right)$, 3.12 (d, 1H, $J=19, \mathrm{H}-4 \mathrm{a}), 3.31$ (d, 1H, $J=19, \mathrm{H}-4 \mathrm{~b}), 6.55$ (s, 1H, OH), 6.84-7.00 (m, 2H, Benzoyl), 7.38-7.47 (m, 1H, Benzoyl), 8.14-8.19 (m, 1H, Benzoyl), 10.69 (s, 1H, 2-OHBenzoyl); ${ }^{13} \mathrm{C}$ NMR (50 MHz, DMSO- $\left.d 6\right): \delta\left(J_{\mathrm{C}-\mathrm{F}}, \mathrm{Hz}\right) 15.2\left(\mathrm{CH}_{3}\right), 47.8(\mathrm{C}-4), 90.8\left(\mathrm{q},{ }^{2} J=34\right.$, C5), 115.9, 118.3, 124.3, 128.2, 130.7, 153.7 (Benzoyl), 123.5 (q, ${ }^{1} J=286, \mathrm{CF}_{3}$ ), 153.5 (C-3), $167.0(\mathrm{C}=\mathrm{O})$; MS: $m / z \%=288\left(\mathrm{M}^{+}, 19\right), 177(9), 121$ (100), 93 (20), 65 (38); Anal. Calcd. for $\mathrm{C}_{12} \mathrm{H}_{11} \mathrm{~F}_{3} \mathrm{~N}_{2} \mathrm{O}_{3}$ : C, 50.01; H, 3.85; N, 9.72. Found: C, 50.03; H, 3.57; N, 9.65.

5-Hydroxy-3-phenyl-5-trifluoromethyl-4,5-dihydro-1 H-1-(2-hydroxybenzoyl)pyrazole (7b). Yield: $4.8 \mathrm{mmol}(96 \%)$; mp 114-116 ${ }^{\circ} \mathrm{C}$; ${ }^{1} \mathrm{H} \mathrm{NMR}\left(200 \mathrm{MHz}, \mathrm{CDCl}_{3}\right): \delta(J, \mathrm{~Hz}) 3.55(\mathrm{~d}, 1 \mathrm{H}, J=$ 19, H4a), 3.75 (d, 1H, $J=19$, H4b), 6.91-7.03 (m, 2H, Benzoyl), 7.42-7.50 (m, 5H, Ph), 7.677.72 (m, 1H, Benzoyl), 8.30-8.35 (m, 1H, Benzoyl), 10.78 (br, 1H, 2-OH-Benzoyl); ${ }^{13} \mathrm{C}$ NMR 
(50 MHz, DMSO-d6): $\delta\left(J_{\mathrm{C}-\mathrm{F}}, \mathrm{Hz}\right) 44.4$ (C-4), 91.7 (q, $\left.{ }^{2} J=34, \mathrm{C}-5\right), 116.0,118.4,123.9128 .7$, 130.6, 151.4 (Benzoyl), 123.6 (q, $\left.{ }^{1} J=286, \mathrm{CF}_{3}\right), 126.6,128.8,130.4,131.2(\mathrm{Ph}), 155.1$ (C-3), $167.4(\mathrm{C}=\mathrm{O})$; MS: $m / z \%=350\left(\mathrm{M}^{+}, 49.5\right), 230$ (89), 213 (71), 161 (100), 138 (20), 121 (100), 93 (69), 65 (88); Anal. Calcd. for $\mathrm{C}_{17} \mathrm{H}_{13} \mathrm{~F}_{3} \mathrm{~N}_{2} \mathrm{O}_{3}$ : C, 58.29; H, 3.74; N, 8.00. Found: C, 57.97; H, $3.72 ;$ N, 7.95 .

5-Hydroxy-3-(4-methylphenyl)-5-trifluoromethyl-4,5-dihydro-1H-1-(2-hydroxybenzoyl) pyrazole (7c). Yield: $4.56 \mathrm{mmol}(91 \%)$; mp 123-125 ${ }^{\circ} \mathrm{C}{ }^{1} \mathrm{H}$ NMR $\left(200 \mathrm{MHz}, \mathrm{CDCl}_{3}\right): \delta(J, \mathrm{~Hz})$ $2.40\left(4-\mathrm{CH}_{3}-\mathrm{C}_{6} \mathrm{H}_{4}\right), 3.53(\mathrm{~d}, 1 \mathrm{H}, J=19, \mathrm{H}-4 \mathrm{a}), 3.73$ (d, 1H, $\left.J=19, \mathrm{H}-4 \mathrm{~b}\right), 6.55$ (s, 1H, OH), 6.90-7.04 (m, 2H, Benzoyl), 7.23-7.27 (m, 2H, $\left.\mathrm{C}_{6} \mathrm{H}_{4}\right), 7.42-7.51$ (m, 1H, Benzoyl), 7.57-7.61 (m, $\left.2 \mathrm{H}, \mathrm{C}_{6} \mathrm{H}_{4}\right), 8.31-8.36$ (m, 1H, Benzoyl), 10.80 (s, 1H, 2-OH-Benzoyl); ${ }^{13} \mathrm{C}$ NMR (100 MHz, DMSO-d6): $\delta\left(J_{\mathrm{C}-\mathrm{F}}, \mathrm{Hz}\right) 21.0\left(4-\mathrm{CH}_{3}-\mathrm{C}_{6} \mathrm{H}_{4}\right), 44.4(\mathrm{C}-4), 91.5\left(\mathrm{q},{ }^{2} J=34, \mathrm{C}-5\right), 115.9,118.3$, 124.0, 128.6, 131.0, 151.3 (Benzoyl), 123.5 (q, $\left.{ }^{1} J=286, \mathrm{CF}_{3}\right), 126.5,127.6,129.3,140.4\left(\mathrm{C}_{6} \mathrm{H}_{4}\right)$, 154.9 (C-3), $167.2(\mathrm{C}=\mathrm{O}) ; \mathrm{MS}: m / z \%=364\left(\mathrm{M}^{+}, 9\right), 244$ (40), 226 (25), 175 (59), 121 (100), 65 (30); Anal. Calcd. for $\mathrm{C}_{18} \mathrm{H}_{15} \mathrm{~F}_{3} \mathrm{~N}_{2} \mathrm{O}_{3}$ : C, 59.34; H, 4.15; N, 7.69. Found: C, 58.99; H, 3.74; N, 7.58 .

\section{3-(4-Bromophenyl)-5-hydroxy-5-trifluoromethyl-4,5-dihydro-1H-1-(2-hydroxybenzoyl)}

pyrazole (7d). Yield: $4.47 \mathrm{mmol}(89 \%)$; mp 131-133 ${ }^{\circ} \mathrm{C} ;{ }^{1} \mathrm{H}$ NMR $\left(200 \mathrm{MHz}, \mathrm{CDCl}_{3}\right): \delta(J, \mathrm{~Hz})$ 3.52 (d, 1H, $J=19, \mathrm{H}-4 \mathrm{a}), 3.72$ (d, 1H, $J=19, \mathrm{H}-4 \mathrm{~b}), 6.54$ (br, 1H, OH), 6.91-7.04 (m, 2H, Benzoyl), 7.43-7.52 (m, 1H, Benzoyl), 7.57-7.62 (m, 4H, $\left.\mathrm{C}_{6} \mathrm{H}_{4}\right), 8.24-8.28$ (m, 1H, Benzoyl), 10.70 (s, 1H, 2-OH-Benzoyl); ${ }^{13} \mathrm{C}$ NMR (50 MHz, DMSO-d6): $\delta\left(J_{\mathrm{C}-\mathrm{F}}, \mathrm{Hz}\right)=44.2(\mathrm{C}-4), 91.7$ $\left(\mathrm{q},{ }^{2} J_{\mathrm{C}-\mathrm{F}}=34, \mathrm{C}-5\right), 115.8,118.3,124.0,128.5,131.1,150.5$ (Benzoyl), 123.3 (q, ${ }^{1} \mathrm{~J}=286 \mathrm{~Hz}$, $\left.\mathrm{CF}_{3}\right), 128.3,129.5,131.8\left(\mathrm{C}_{6} \mathrm{H}_{4}\right), 154.8(\mathrm{C}-3), 167.1(\mathrm{C}=\mathrm{O})$; MS: $m / z \%=428\left(\mathrm{M}^{+}, 29\right), 308$ (76), 292 (62), 239 (74), 138 (43), 121 (100), 93 (85), 65 (89); Anal. Calcd. for $\mathrm{C}_{17} \mathrm{H}_{12} \mathrm{BrF}_{3} \mathrm{~N}_{2} \mathrm{O}_{3}$ : C, 47.57; H, 2.82; N, 6.53. Found: C, 47.33; H, 2.67; N, 6.35.

\section{3-(4-Fluorophenyl)-5-hydroxy-5-trifluoromethyl-4,5-dihydro-1H-1-(2-hydroxybenzoyl)}

pyrazole (7e). Yield: $4.27 \mathrm{mmol}(85 \%) ; \mathrm{mp} 122-124^{\circ} \mathrm{C} ;{ }^{1} \mathrm{H}$ NMR $\left(200 \mathrm{MHz}, \mathrm{CDCl}_{3}\right): \delta(J, \mathrm{~Hz})$ 3.53 (d, 1H, $J=19, \mathrm{H}-4 \mathrm{a}), 3.73$ (d, 1H, $J=19, \mathrm{H}-4 \mathrm{~b}), 6.54$ (s, 1H, OH), 6.91-7.04 (m, 2H, Benzoyl), 7.10-7.19 (m, 2H, $\left.\mathrm{C}_{6} \mathrm{H}_{4}\right)$, 7.43-7.52 (m, 1H, Benzoyl), 6.67-7.74 (m, 2H, $\left.\mathrm{C}_{6} \mathrm{H}_{4}\right)$, 8.268.31 (m, 1H, Benzoyl), 10.72 (s, 1H, 2-OH-Benzoyl); ${ }^{13} \mathrm{C}$ NMR (50 MHz, DMSO-d6): $\delta\left(J_{\mathrm{C}-\mathrm{F}}\right.$, Hz) 44.4 (C-4), 91.7 (q, $\left.{ }^{2} J=35 \mathrm{~Hz}, \mathrm{C}-5\right), 115.9$ (d, $\left.{ }^{2} J=22 \mathrm{~Hz}, \mathrm{C}_{6} \mathrm{H}_{4}\right), 126.9$ (d, ${ }^{4} J=3 \mathrm{~Hz}, \mathrm{C}_{6} \mathrm{H}_{4}$ ), $128.9\left(\mathrm{~d},{ }^{3} \mathrm{~J}=9 \mathrm{~Hz}, \mathrm{C}_{6} \mathrm{H}_{4}\right), 163.4\left(\mathrm{~d},{ }^{1} \mathrm{~J}=249 \mathrm{~Hz}, \mathrm{C}_{6} \mathrm{H}_{4}\right), 123.4\left({ }^{1} \mathrm{~J}=286 \mathrm{~Hz}, \mathrm{CF}_{3}\right), 115.9,118.4$, 124.0, 128.6, 131.1, 150.5 (Benzoyl), 154.9 (C-3), $167.2(\mathrm{C}=\mathrm{O})$; MS: $m / z \%=368\left(\mathrm{M}^{+}, 34\right), 248$ (62), 230 (46), 179 (91), 138 (36), 121 (100), 93 (84), 65 (97); Anal. Calcd. for $\mathrm{C}_{17} \mathrm{H}_{12} \mathrm{~F}_{4} \mathrm{~N}_{2} \mathrm{O}_{3}$ : C, 55.44; H, 3.28; N, 7.61. Found: C, 55.44; H, 3.09; N, 7.62.

5-Hydroxy-4-methyl-5-trifluoromethyl-4,5-dihydro-1H-1-(2-hydroxybenzoyl)pyrazole (7f). Yield: $4.36 \mathrm{mmol}(87 \%)$; $\mathrm{mp} 83-85^{\circ} \mathrm{C}$; ${ }^{1} \mathrm{H} \mathrm{NMR}\left(200 \mathrm{MHz}, \mathrm{CDCl}_{3}\right): \delta(J, \mathrm{~Hz}) 1.30(\mathrm{~d}, 3 \mathrm{H}, J=7$, $\mathrm{R}^{2}$ ), 3.48 (qd, $\left.J=7 \mathrm{~Hz}, J=1 \mathrm{~Hz}, \mathrm{H}-4\right), 6.54$ (s, 1H, OH), 6.85-7.01 (m, 2H, Benzoyl), 6.97 (s, 1H, H-3), 7.39-7.47 (m, 1H, Benzoyl), 8.04-8.09 (m, 1H, Benzoyl), 10.52 (s, 1H, 2-OHBenzoyl); ${ }^{13} \mathrm{C}$ NMR (50 MHz, DMSO-d6): $\delta\left(J_{\mathrm{C}-\mathrm{F}}, \mathrm{Hz}\right) 9.5\left(\mathrm{CH}_{3}\right), 48.3(\mathrm{C}-4), 89.9\left(\mathrm{q},{ }^{2} J_{\mathrm{C}-\mathrm{F}}=33\right.$, C-5), 115.8, 118.3, 124.2, 128.2, 130.7, 149.6 (Benzoyl), 123.7 (q, $\left.{ }^{1} J=286 \mathrm{~Hz}, \mathrm{CF}_{3}\right), 154.4$ (C- 
3), $167.8(\mathrm{C}=\mathrm{O})$; MS: $m / z \%=288\left(\mathrm{M}^{+}, 20\right), 163$ (39), 121 (100), 93 (30), 65 (47); Anal. Calcd. for $\mathrm{C}_{12} \mathrm{H}_{11} \mathrm{~F}_{3} \mathrm{~N}_{2} \mathrm{O}_{3}$ : C, 50.01; H, 3.85; N, 9.72. Found: C, 50.31; H, 3.97; N, 9.75.

\section{Acknowledgements}

The authors thank the Conselho Nacional de Desenvolvimento Científico e Tecnológico (CNPq/PRONEX) and Fundação de Amparo à Pesquisa do Estado do Rio Grande do Sul (FAPERGS) for financial support, as well as Dr. R. A. Burrow, for solving the crystal structures. Fellowships from CNPq and CAPES are also acknowledged.

\section{References and Notes}

1. (a) Elguero, J. In: Comprehensive Heterocyclic Chemistry II, Vol. 3; Katritzky, A. R.; Rees, C. W.; Scriven, E. F. V., Eds.; Pergamon: Oxford, 1996, 1. (b) Katritzky, A. R; Wang, M.; Zhang, S.; Voronkov, M. V. J. Org. Chem. 2001, 66, 6787; and references therein.

2. (a) Kees, K. L.; Fitzgerald, J. J. Jr.; Steiner, K. E.; Mattes, J. F.; Mihan, B.; Tosi, T.; Mondoro, D.; McCaleb, M. L. J. Med. Chem. 1996, 39, 3920. (b) Genin, M. J.; Biles, C.; Keiser, B. J.; Poppe, S. M.; Swaney, S. M.; Tarpley, W. G.; Yagi, Y.; Romero, D. L. J. Med. Chem. 2000, 43, 1034. (c) Manfredini, S.; Bazzanini, R.; Baraldi, P. G.; Guarneri, M.; Simoni, D.; Marongiu, M. E.; Pani, A.; Tramontano, E.; Colla, P. L. J. Med. Chem. 1992, 35, 917. (d) Jungheim, L. N. Tetrahedron Lett. 1989, 30, 1889. (e) Dannhardt, G.; Laufer, S. Curr. Med. Chem. 2000, 7, 1101. (f) Penning, T. D.; Talley, J. J.; Bertenshaw, S. R.; Carter, J. S.; Collins, P. W.; Docter, S.; Graneto, M. J.; Lee, L. F.; Malecha, J. W.; Miyashiro, J. M.; Rogers, R. S.; Rogier, D. J.; Yu, S. S.; Anderson, G. D.; Burton, E. G.; Cogburn, J. N.; Gregory, S. A.; Koboldt, C. M.; Perkins, W. E.; Seibert, K.; Veenhuizen, A. W.; Zhang, Y. Y.; Isakson, P. C. J. Med. Chem. 1997, 40, 1347.

3. Vane, J. R. Nat. New. Biol. 1971, 231, 232. (b) Campos, C.; Gregorio, R.; García-Neto, R.; Gago, F.; Ortiz, P.; Alamany, S. Eur. J. Pharmacol. 1999, 378, 339.

4. Tortorici, V.; Vasquez, E.; Venegas, H. Brain Res. 1996, 725, 106.

5. Lorenzetti, B. B.; Ferreira, S. H. Inflamm. Res. 1996, 45, 308.

6. Beirith, A.; Santos, A. R. S.; Rodrigues, A. L. S.; Creczynsky-pasa, T. B.; Calixto, J. B. Eur. J. Pharmacol. 1998, 345, 233.

7. (a) Martins, M. A. P.; Cunico, W.; Pereira, C. M. P.; Sinhorin, A. P.; Flores, A. F. C.; Bonacorso, H. G.; Zanatta, N. Curr. Org. Synthesis 2004, 1, 391; and references therein. (b) Martins, M. A. P.; Pereira, C. M. P.; Moura, S.; Fiss, G. F.; Frizzo, C. P.; Emmerich, D. J.; Zanatta, N.; Bonacorso, H. G. ARKIVOC 2006, (xiii), 187.

8. (a) Spiegler, W.; Götz, N. Synthesis 1986, 69. (b) Martins, M. A. P.; Flores, A. F. C.; Bastos, G. P.; Sinhorin, A.; Bonacorso, H. G.; Zanatta, N. Tetrahedron Lett. 2000, 41, 293. (c) 
Martins, M. A. P.; Freitag, R.; Flores, A. F. C.; Zanatta, N. Synthesis 1995, 1491.

9. Martins, M. A. P.; Freitag, R. A.; Rosa, A.; Flores, A. F. C.; Zanatta, N.; Bonacorso, H. G. $J$. Heterocycl. Chem. 1999, 36, 217.

10. (a) Palacios, F.; Retana, A. M. O.; Pagalday, J. Tetrahedron 1999, 55, 14451. (b) Padwa, A.; MacDonald, J. G. J. Heterocycl. Chem. 1987, 24, 1225. (c) Padwa, A.; Kulkarni, Y.; Zhang, Z. J. Org. Chem. 1990, 55, 4144.

11. (a) Tietze, L. F.; Meier, H.; Voß, E. Synthesis 1988, 274. (b) Haider, A.; Wyler, H. Helvet. Chim. Acta 1983, 66, 606. (c) Croxall, W. J.; Schneider, H. J. Patent 2550042: Chem. Abstr. 1951, 45, 50056.

12. (a) Souza, F. R.; Fighera, M. R.; Lima, T. T. F.; Bastiani, J.; Barcellos, I. B.; Almeida, C. E.; Oliveira, M. R.; Bonacorso, H. G.; Flores, A. E.; Mello, C. F. Pharm. Biochem. Behav. 2001, 68, 525. (b) Godoy, M. C. M.; Fighera, M. R.; Souza, F. R.; Flores, A. E.; Rubin, M. A.; Oliveira, M. R.; Zanatta, N.; Martins, M. A. P.; Bonacorso, H. G.; Mello, C. F. Eur. J. Pharmacol. 2004, 496, 93. (c) Souza, F. R.; Ratzlaff, V. T.; Borges, L. P.; Oliveira, M. R.; Bonacorso, H. G.; Zanatta, N.; Martins, M. A. P.; Mello, C. F. Eur. J. Pharmacol. 2002, 451, 141. (d) Tomazetti, J.; Ávila, D. S.; Ferreira, A. P. O.; Martins, J. S.; Souza, F. R.; Royer, C.; Rubin, M. A.; Oliveira, M. R.; Bonacorso, H. G.; Martins, M. A. P.; Zanatta, N.; Mello, C. F. J. Neurosci. Meth. 2005, 147, 29. (e) Tabarelli, Z.; Rubin, M. A.; Berlese, D. B.; Sauzem, P. D.; Missio, T. P.; Teixeira, M. V.; Sinhorin, A. P.; Martins, M. A. P.; Zanatta, N.; Bonacorso, H. G.; Mello, C. F. Braz. J. Med. Biol. Res. 2004, 37, 1531.

13. Lazar, C.; Kluczyk, A.; Kiota, T.; Konishi, Y. J. Med. Chem. 2004, 47, 6973.

14. Martins, M. A. P.; Bastos, G. P.; Bonacorso, H. G.; Zanatta, N.; Flores, A. F. C.; Siqueira, G. M. Tetrahedron Lett. 1999, 40, 4309.

15. Wohl, R. A. Synthesis 1974, 38.

16. Gypser, A.; Kirstgen, R.; Sauter, H.; Bayer, H.; Cullmann, O.; Gewehr, M.; Grammenos, W.; Muller, B.; Ptock, A.; Blasco, J. T.; Ammermann, E.; Grote, T.; Lorenz, G.; Strathmann, S. PCT Int. Appl. 2000020399: Chem. Abstr. 2000, 132, 279215.

17. (a) Lin, P.; Jiang, J. Tetrahedron 2000, 56, 3635. (b) Arnone, A.; Bernardi, R.; Blasco, F.; Cardillo, R.; Resnati, G.; Gerus, I. I.; Kukhar, V. P. Tetrahedron 1998, 54, 2809.

18. Farrugia, L. J. J. Appl. Crystallogr. 1997, 30, 565.

19. Khan, K. M.; Rasheed, M.; Zia-Ullah; Hayat, S.; Kaukab, F.; Choudhary, M. I.; Atta-urRahman; Perveen, S. Bioorg. Med. Chem. 2003, 11, 1381.

20. (a) Martins, M. A. P.; Colla, A.; Fischer, P.; Krimmer, S. Synthesis 1991, 483. (b) Bonacorso, H. G.; Lopes, I. S.; Wastowski, A. D.; Zanatta, N.; Martins, M. A. P. J. Fluorine Chem. 2003, 120, 29.

21. (a) Dewar, M. J. S.; Zoebisch, E. G.; Healey, E. F.; Stewart, J. J. P. J. Am. Chem. Soc. 1985, 107, 3902. (b) HyperChem Hypercube, Inc., Waterloo, Ontario, Canada, 2002.

22. Martins, M. A. P.; Flores, A. F. C.; Freitag, R. A.; Zanatta, N.; Hörner, M.; Bortoluzzi, A. J. Spectrosc. Lett. 1997, 30, 661.

23. Full crystallographic data for structures reported in this paper have been deposited with the 
Cambridge Crystallographic Data Center. Copies of the data can be obtained, free of charge, on application to CCDC, 12 Union Road, Cambridge CB2 1EZ, UK (Fax: +44-01223336033) or via www.cam.ac.uk/datarequest/cif.

24. Hayashi, G.; Takemori, A. E. Eur. J. Pharmacol. 1971, 16, 63.

25. Perrin, D. D.; Armarego, W. L. F. In Purification of Laboratory Chemicals; Pergamon: Oxford, 1998.

26. SHELXTL 6.14; Bruker AXS Inc.: Madison WI, 2003.

27. Farrugia, L. J. J. Appl. Crystallogr. 1999, 32, 837. 